\title{
The internal syntax of Q-words
}

\author{
Karen De Clercq \\ FWO/U Gent
}

\begin{abstract}
This paper presents typological data from Q(uantity)-words, i.e. of MANY/MUCH and FEw/LitTLE. I propose to syntactically decompose Q-words in a Q, Div and Num feature, with Neg being added for negative Q-words. Support for this decomposition comes from syncretism patterns between mass and count Q-words, and morphologically visible sentential negation in negative Q-words. I present a nanosyntactic analysis, in which the size of a lexically stored tree for count Q-words is bigger than the size of mass Q-trees. As such, language variation in the domain of Q-words can be captured by varying the size of lexically stored trees (Starke 2014). Finally, I show that thanks to the Superset Principle, a sentential negative marker can be used to Spellout a Neg-feature in the absence of a lexical item for FEw/LITTLE.
\end{abstract}

\section{Introduction}

MANY/MUCH and FEW/LiTTLE belong to a group of quantifiers that has been referred to as semilexical categories (Corver \& van Riemsdijk 2013), degree determinatives (Huddleston \& Pullum 2002:393), vague quantifiers or value judgement quantifiers (Partee 1989; Keenan \& Paperno 2012), Q-adjectives (Solt 2015) or Quantity-words (Rett 2016). I will adopt the term Q(uantity)words for the remainder of this paper.

The reason for these various labels are the diverse distributional properties of these words, which share characteristics with adjectives, nouns, numerals, and quantifiers. Adjectival characteristics include the presence of comparative and superlative forms (e.g. more/most and less/least). They can be used predicatively and attributively (with certain language specific restrictions, such as the fact that English mass Q-words cannot be used in predicative position):

a. John's friends are many/few. (predicative)

b. The many/few students who attended enjoyed the lecture. (attributive)

(2) a. *The water in the bucket was much/little. (predicative)

b. The little/*much water in the bucket. (attributive) 
A further property that Q-words share with gradable adjectives is that their interpretation relies on a contextual dimension, i.e. the context determines the standard for what is perceived as MUCh/MANy and Little/Few (Partee 1989). Both the positive Q-words and the negative Qwords (henceforth NQ-words) share the property of denoting a vague quantity, which ranges along the positive or negative dimension of a scale.

A somewhat underreported use of Q-words is their ability to function as adjectival modifiers; this use is subject to various polarity restrictions (such as the fact that MUCH cannot be used in attributive position with adjectives in the equative degree, but LiTTLE can, e.g. (3)), whereas both can be used with the comparative degree, (4):

(3) Jacques est peu intelligent.

Jacques is little intelligent

'Jacques is not intelligent.'

(4) a. Jack is more intelligent than Sue.

b. John drove much/little faster than Sue.

The mass Q-word can also be used as an adverbial with verbal predicates:
a. John sleeps little.
b. Does John sleep much?

A nominal characteristic of Q-words is the fact that in some languages, e.g. English, they have separate items for mass and count. Even languages that do not have specific count Q-words can sometimes track the mass-count distinction by means of plural morphology:

(6) Romanian
a. mult nisip much sand.MAsC
b. mulţ-i studenț-i many-PL student.MASC-PL
c. mult-e studente many-PL student.FEM-PLS (p.c. Sebastian Bican and Carmen Florina)

Their incompatibility with cardinal numerals suggests that they also have numeral properties: 

a. these many books
b. these three books
c. *these three many books

Finally, Q-words can also scopally interact with other quantifiers, a property they share with quantifiers like all, every, .... I will not discuss this in the present paper and refer the reader to Beghelli (1995) and Heim (2006)) amongst others. This overview of the essential uses of Q-words is far from exhaustive. More examples can be found in Solt (2015:221); Rett (2016).

The structure of this paper is as follows. In section 2 a sample of typological data will be discussed and four typological patterns will be identified. These patterns will be the input for the feature system underlying Q-words, which will be set up in section 3. In section 4, a nanosyntactic analysis will be provided for 3 different typological patterns in the sample, of which English, Dutch and Malagasy are representatives. Nanosyntax will turn out to be an ideal candidate to capture language variation in the size of lexically stored trees. Section 5 summarizes and concludes.

\section{The data}

When it comes to how the grammar of Q-words is organised, languages make choices within two intersecting domains, the mass/count distinction on the one hand, and the positive/negative distinction on the other. The cross-section of these two distinctions yields the following matrix of oppositions:

\begin{tabular}{l|l|l} 
& count & mass \\
\hline positive & & \\
\hline negative & &
\end{tabular}

These oppositions are subject to cross-linguistic variation along the following parameters. With respect to the mass-count distinction, Q-words can be syncretic or not. If they are syncretic, the syncretism can stretch along the positive dimension of the scale, along the negative dimension or along both. As far as negation is concerned, languages may make use of overt negative morphology, and hence be analytic, or they have an opaque form. 
Table 1 illustrates positive and negative Q-words in 21 different languages, ranging from language families as diverse as Indo-European (English, Swedish, Dutch, French, Romanian, Italian, Greek, Western Armenian and Czech), Finno-Ugric (Hungarian), Dravidian (Telugu), Semitic (Hebrew), Austronesian (Malagasy), Niger-Congo (Wolof and Northern Sotho), San (Höã), Altaic (Japanese), Sino-Tibetan (Chinese), Arawakan (Garifuna), Caribbean (Hixkaryana), and Uto-Aztecan (Tümpisa). Even though the language sample is small, it is highly diversified, with languages from different phyla, following sampling methods discussed in Rijkhoff et al. (1993) and Baker \& McCloskey (2007)'s Middle Way approach to typologically driven theoretical research. ${ }^{1}$

There seem to be three restrictions with respect to NQ-words. These are listed below:
a. Only sentential negative markers are used in analytic NQ-words.
b. A mass NQ-word is only analytic if the count NQ-word is also analytic.
c. If there is an analytic NQ-word, the positive dimension is syncretic.

The typological sample offers four distinct attested patterns with respect to the parameters of variation just discussed. In what follows I discuss these four patterns and zoom in on one language per pattern: English, Dutch, Malagasy and Western Armenian.

\subsection{Pattern 1: English}

A language that is fully non-syncretic for mass and count along the positive and negative dimension and that makes use of opaque forms for NQ-words is English, but also Swedish and Höã. The pattern is schematically illustrated in (10).

\begin{tabular}{l|ll} 
& count & mass \\
\hline positive & many & much \\
negative & few & little
\end{tabular}

The distribution of English many/much and few/little was already briefly discussed in section 1 .

1 ?'s (?) grammar of Hixkaryana does not describe which word is used to express LiTtLE in Hixkaryana. I have not find another source that could give me that information. 


\begin{tabular}{|c|c|c|c|}
\hline & MANY/MUCH & FEW/LITTLE & S-NEG \\
\hline & count mass & count & \\
\hline English & many much & little & not \\
\hline Swedish & många mycket & lite & inte \\
\hline Höã & kí-ǰöa kăo & |x’ǔi & |hö’õ \\
\hline Dutch & veel & weinig & niet \\
\hline Hebrew & meat & harbe & lo \\
\hline Mandarin & $\mathrm{d} \overline{u o}$ & shăo & bù \\
\hline Czech & mnoho & málo & ne \\
\hline French & beaucoup & peu & pas \\
\hline Romanian & mult- & puţin- & nu \\
\hline Italian & molt- & poc- & non \\
\hline Greek & pol- & LÍG- & dhen \\
\hline Hungarian & sok & keves & nem \\
\hline Tümpisa & so’oppüh & tütüttsi(ttsi) & ke \\
\hline Telugu & ĕk:ŭvă/čaala & tăk:ŭvă & le- \\
\hline Malagasy & betsaka & vi-tsy kely & tsy \\
\hline N Sotho & $-n t s ̌ i$ & se-kae $\quad$-nnyane & se \\
\hline Wolof & bëri & bëri-wul tuuti & $-\mathbf{u}(\mathbf{l})$ \\
\hline Hixkaryana & thenyehra & yak-hera - & -hira \\
\hline & yake ? & & \\
\hline Japanese & takusan & $\begin{array}{c}\text { hotondo }+ \text { wh }+ \text { mo }+ \text { nai } \\
\text { suku-nai }\end{array}$ & - nai \\
\hline Garifuna & $\begin{array}{l}\text { g-ibe- } \\
\text { sarágu }\end{array}$ & $\begin{array}{c}\text { m-ibe } \\
\text { mama sarágu }\end{array}$ & m-(a) \\
\hline Western Armenian & $\int \mathrm{ad}$ & ki-t $\int$ & $\mathbf{t} \int(\mathbf{i} / \boldsymbol{\partial})$ \\
\hline
\end{tabular}

Table 1: Typology of Q-words. 


\subsection{Pattern 2: Dutch}

The pattern we see in Dutch, and also in French, Romanian, Italian, Greek, Czech, Hungarian, Hebrew, Mandarin, Tümpisa and Telugu in the sample is schematized in (11). Both the positive and the negative dimension have a syncretic marker and the NQ-word is opaque.

(11)

\begin{tabular}{l|ll} 
& count & mass \\
\hline positive & veel & veel \\
negative & weinig & weinig
\end{tabular}

For reasons of space, I do not give any further Dutch examples here, but Dutch Q-words can for the most part be used like the English ones, i.e. as quantifiers, in attributive and predicative position and as adverbs.

\subsection{Pattern 3: Wolof}

The third pattern in the sample is exemplified by Wolof, Northern Sotho and Malagasy. In this pattern positive Q-words are syncretic for the mass-count distinction. NQ-words show a split: the count word is analytic and the mass form is opaque.

\begin{tabular}{l|ll} 
& count & mass \\
\hline positive & bëri & bëri \\
negative & bëri-wul & tuuti
\end{tabular}

MANY/MUCH in Wolof is expressed by means of a stative verbal predicate in a relative clause construction (Tamba et al. 2012:927):
a. Góór y-u
bëri d-u-nu
tux.
man CL.PL-C $\mathrm{C}_{\text {Rel }}$ be.many IMPERF-NEG-3PL smoke 'Many men don't smoke.'

b. Xadi gis-na góór y-u bëri.

Xadi see-FIN man CL.PL- $\mathrm{C}_{\text {rel }}$ be.many

'Xadi saw many men.'
a. Xadi naan-na meew $\mathrm{m}-\mathrm{u}$ bëri.
Xadi drink-FIN milk CL-C ${ }_{r e l}$ BE.MUCH
'Xadi drank a lot of milk.'


b. Meew m-u bëri tuur-u-na.

milk CL- $\mathrm{C}_{\text {rel }}$ be.much spill-REFL-FIN

'A lot of milk spilled.'

For FEW/LITTLE a different quantificational expression is used with mass and count nouns. With count nouns a transparent construction is used, with the sentential negative marker $-u(l)$ and the verbal predicate bëri 'many' (Tamba et al. 2012:927). ${ }^{2}$
Xaj $y-u$
bëri-wul
mën a jáng.

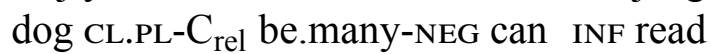
'Few/Not many dogs can read.'

With mass nouns the adjectival predicate tuuti 'little, small' is used. (16a) illustrates tuuti as the adjective denoting 'small' and (16b) as the quantifier, meaning 'little' (Tamba et al. 2012:928).
a. Xaj b-i am-na nopp y-u tuuti. dog CL-DEF/PROX have-FIN ear CL-C $\mathrm{C}_{\text {Rel }}$ small 'The dog has small ears.'
b. Xadi lekk-na tuuti ceeb. xadi eat-FIn small rice 'Xadi ate some/little rice.'

\subsection{Pattern 4: Western Armenian}

The pattern exemplified by Western Armenian, Garifuna and Japanese displays a count-mass syncretism along the positive dimension and a syncretism along the negative dimension with an analytic negative marker.

\begin{tabular}{l|ll} 
& count & mass \\
\hline positive & Jad & Jad \\
negative & ki-t $\int$ & ki-t $\int$
\end{tabular}

The quantifier $\int a d$ 'much/many' can be used to quantify over mass and count nouns, both independently, as a modifier ((18a) and (18b)), and as an adverb (18c) (Khanjian 2012:848).

2 There are two other ways to express sentential negation: by means of two auxiliaries $b \widetilde{a} n \tilde{n} a ́ k k$ and by means of $d-u$. I will not discuss these strategies here. The regular sentential negative marker is $-u(l)$, which drops the final -1 when it precedes subject markers or clitics. cf. Torrence (2013) for more details on negation in Wolof. 

a. ners-ə fad mart gar inside-def many man $\exists$.PAST.3S
'There were a lot of people inside.'
b. Jad-(mə) a agerd-ner dun ka-ts-in many-INDEF student-PL house go-PAST-3PL
'Many students went home.'
c. $\quad$ ad $\chi ə m e-t s-i r ?$ much drink-PAST-2S
'Did you drink a lot?'

I want to propose that what at first sight looks like a monomorphemic and opaque quantifier, i.e. kitf 'few/little', actually consists of the sentential negative marker $t$ f- and an opaque morpheme $k i$-. A similar analysis could be proposed for the more obviously decomposable vo-tf ‘no’ (Khanjian 2012:847ff).
a. kitf-(mə) afagerd dun kəna-ts. few-indef student house go-PAST.3s
'(A) small amount of students went home.'
b. kit kini
some wine
c. $\quad$ kit $\int$ əome-ts-ir?
few drink-PAST-2S
'Did you drink a little?'

\section{The feature system of $Q$-words}

Based on the typological evidence presented in the previous section, the attested patterns and arguments from the literature, I propose that the functional sequence of Q-words consists at least of a Q feature (for Quantity), a Div feature (Divider), a Num feature (Numeral), and a Neg feature (Negation).

Before I discuss the these four different features in more detail, I want to briefly discuss the categorial nature of Q-words. As we saw in section 1 above, Q-words share properties with adjectives, adverbs, quantifiers, nouns, and numerals. I suggest that this behaviour follows from the fact that they lack what defines rich lexical items, namely a root feature, and consist uniquely of features that otherwise make up the functional superstructure of lexical categories. Q-words have a $\mathrm{Q}$ as their anchor, a feature that is compatible with adjectival, verbal and adverbial categories (see Neeleman et al. (2006) for more discussion of cross-categorial modifiers). 
Schematically, the situation can be represented in (20), which shows the structure of the adjectival $f_{\text {seq }}$ on the first line, the nominal one on the second, and the Q-words on the third (for CMPR and SPRL, see Bobaljik 2012).

$\begin{array}{lllllllll}\text { adjectival } & & & & \text { SPRL } & \text { CMPR } & \text { Q } & \text { a } & \sqrt{ } \\ \text { nominal } & \text { Det } & \text { Num } & \text { Div } & & & & n & \sqrt{ } \\ \text { Q-words } & & \text { Num } & \text { Div } & \text { SPRL } & \text { CMPR } & \text { Q } & & \end{array}$

The Q-feature contributes scalarity or gradability (De Clercq 2013; 2017). Q is a feature that has its origin in the (Split) Degree Hypothesis (Bresnan 1973; Corver 1997). Corver introduced Q as part of the extended functional projection of adjectives, where it served as the host for such adjectival modifiers as much, more, less, enough. The other projection in the extended functional projection line of AP is DegP, which hosts elements like how, so, that, etc., and which I will not discuss in any detail in the present paper. Unlike Corver, I argue that the elements which he argues are merged in Q consist of a Q-feature, i.e. Q is part of their internal structure.

Whereas $\mathrm{Q}$ is a necessary feature to express quantity, the Div feature is a crucial ingredient of any Q-word associated with countable or 'individuated' nominals (Cowper \& Hall 2012). Div is responsible for cutting up the mass in plural mass (cf. Borer's (2005) work on the extended functional projection line of NP). Borer thus argues for a structural account of the [mass]/ [count] distinction. ${ }^{3}$ The sample in 1 provides immediate support for a mass-count distinction within the system of Q-words: English, Swedish and Höã use morphologically different form to distinguish between mass and count. Malagasy, Northern Sotho and Wolof provide a mass-count distinction along the negative dimension.

The cardinality feature Num is responsible for assigning a specific quantity to the pluralized or individuated mass (Borer 2005; sometimes represented as \# in the literature, e.g. Ritter 1992). The presence of the Num feature accounts for the numeral characteristics of Q-words, in particular their incompatibility with cardinal numerals (see (7) above).

NQ-words differ from positive Q-words in the presence of a Neg feature. Support for this feature comes from languages in the sample with an overt negative marker to express the meaning of Few/LitTLE, i.e. the languages below the dividing line in the table. Evidence for the presence of syntactic Neg in nonanalytic languages comes from three tests: the question tag test

\footnotetext{
${ }^{3}$ Unlike Borer I will not use ClP (ClassifierPhrase) to refer to the phrase headed by Div, but DivP.
} 
(Klima 1964), (21a), inversion test, (21b) and NPI-licensing test, (21c). Few/LitTLE behaves like sentential negation under these tests.

a. Few government representatives visited the colonies this year, did they? (Brasoveanu et al. 2014:188)

b. Very few people would they admit to their club. (Collins \& Postal 2014:138)

c. Few changes have ever taken so many people by surprise. (Quirk et al. 1985:780)

For LitTLE as well, it has been shown by De Clercq \& Vanden Wyngaerd (2017:157) that there is reason to assume the presence of a Neg feature even in those languages which show no overt morphological marking of negation. The evidence comes from the combination of LITTLE in French and Dutch with negative gradable predicates. Both in French and Dutch peu and weinig are incompatible with negative gradable predicates, as illustrated by the examples in (22)-(23).

$$
\begin{aligned}
& \text { tolérant/*intolérant 'tolerant/intolerant' } \\
& \text { peu patient/*impatient 'patient/impatient' } \\
& \text { content/*mécontent 'satisfied/dissatisfied' } \\
& \text { interessant/*saai 'interesting/boring' } \\
& \text { weinig duidelijk/*onduidelijk 'clear/unclear' } \\
& \text { geduldig/*ongeduldig 'patient/impatient' }
\end{aligned}
$$

De Clercq \& Vanden Wyngaerd (2017) explain this as a consequence of a restriction on permissible functional sequences: two adjacent negative heads are not permitted in the functional sequence. Assuming both negative adjectives and the modifier weinig/peu 'little' to contain a Neg feature, they explain the contrast in (23) as a violation on this restriction in the functional sequence.

Summarising, Q-words contain at least a Q, Div and Num feature, as well as a Neg feature in the case of NQ-words. In the next section I will propose an analysis which captures the existing patterns discussed in section 2 and shows how language variation boils down to the size of lexically stored trees (Starke 2014). 


\section{Analysis}

I first briefly introduce nanosyntax; next I discuss in more detail how some of the different patterns discussed above can be derived within a nanosyntactic system.

\subsection{Prerequisites for the analysis}

The analysis presented in this paper is couched in the nanosyntactic framework (Starke 2009; 2014; Caha 2009). Nanosyntax has a postsyntactic lexicon, which contains lexical trees, which are themselves created by syntax. Spellout is cyclic and phrasal. After each Merge step, the lexicon is checked at the level of the phrase. Whenever the lexicon has a matching lexical item, the lexical item can be inserted. If there is no identical match, the Superset Principle and the Elsewhere Condition govern lexical insertion. If no match can be found, movement is allowed in order to spellout the newly merged feature.

(24) Superset Principle (Starke 2009:3)

A lexically stored tree matches a syntactic node iff the lexically stored tree contains the syntactic node.

Elsewhere Condition or Minimize Junk (Caha 2009:18)

In case two rules, R1 and R2, can apply in an environment E, R1 takes precedence over $\mathrm{R} 2$ if it applies in a proper subset of environments compared to R2.

I will explain how spellout works in more detail when I present the analysis. For more information on the model itself, I refer the reader to Starke (2009); Baunaz et al. (to appear).

\subsection{The grammar of $Q$-words}

The basic functional sequence of Q-words is depicted in (26): 


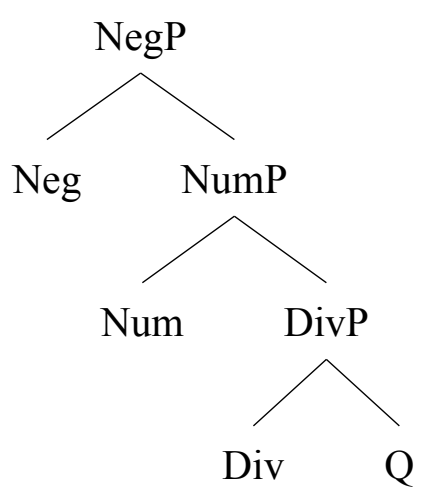

In what follows I will discuss in more detail three different patterns in the sample: one with opaque syncretic Q-words (Dutch), one with non-syncretic opaque Q-words (English) and one with an analytic count Q-word along the negative dimension (Wolof).

The lexical items of English Q-words are in (27). The lexicon of English contains four Qwords, given that English has distinct lexicalisations for the four cells of the mass/count and positive/negative matrix structure.
a. $</$ much/, [QP Q] $>$
b. $</$ many/, [NumP Num [DivP Div Q ]] >
c. $\quad</$ little/, [NegP Neg Q ] >
d. $</$ few/, [NegP Neg [NumP Num [DivP Div Q ]]] >

In terms of the tree in (26), it is easy to see that much spells out QP, many spells out NumP, and few spells out the complete tree (i.e. NegP). The only special case is little, which spells out the tree in (26) without the NumP and DivP projection in the middle, since these are the projections associated with count.

For the Dutch pattern, deriving the syncretism in the positive Q-words is straightforward, given the following lexical entry for veel. ${ }^{4}$

$$
</ \text { veel/, [NumP [DivP [QP ]]] }>
$$

This lexical item can spell out either the tree in (29), or a tree just conisting of the single Q feature, thanks to the Superset Principle. This accounts for the mass/count syncretism.

\footnotetext{
${ }^{4}$ See Ruys (2017), Barbiers (2007) and Broekhuis \& den Dikken (2012:925) for more extensive discussion of veel.
} 


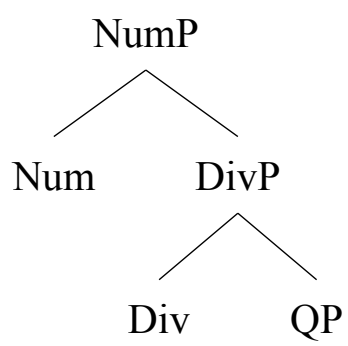

The lexical item weinig 'little/few' must also be able to spell out the two different syntactic structures in (30) and (31), given that weinig 'little/few' is syncretic for the mass/count distinction:

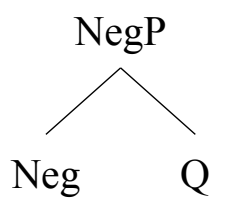

$(31)$

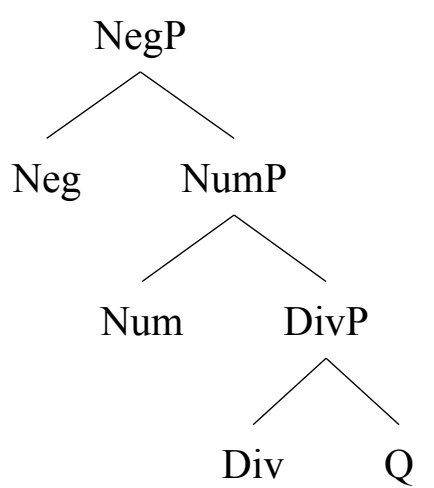

There is a problem now if we assume that the lexical entry for weinig 'little/few' is as in (32):

$$
</ \text { weinig/, [NegP Neg [NumP Num [DivP Div Q ]]] }>
$$

This lexical item cannot spell out the syntactic tree in (30) since the lexical tree does not contain the syntactic tree as a subtree, i.e. the syntactic tree has shrunk in the middle. I propose to solve this by means of the mechanism of pointers, as proposed in Caha \& Pantcheva (2012). Concretely, the lexical entry for weinig 'little/few' contains a Neg feature, and a pointer to the lexical entry for veel 'much/many'. As we saw, thanks to the Superset Principle veEL can also spell out just Q.

$$
</ \text { weinig/, [NegP Neg VEel ] }>
$$

In Wolof the situation is quite different, at least for the negative items: the negator responsible for sentential negation is part of the structure of the negative count Q-word. The lexical item for BËRI 'many/much' is in ??. 
This lexical item can capture the syntactic strucures for count and mass, as already illustrated for veel 'many/much' above. The situation with respect to the lexical item for LITTLE is similar to the English pattern, however. The item in (35) is the only match when syntax merges the structure in (36).

$$
</ \text { tuuti/, [NegP Neg Q]] > }
$$

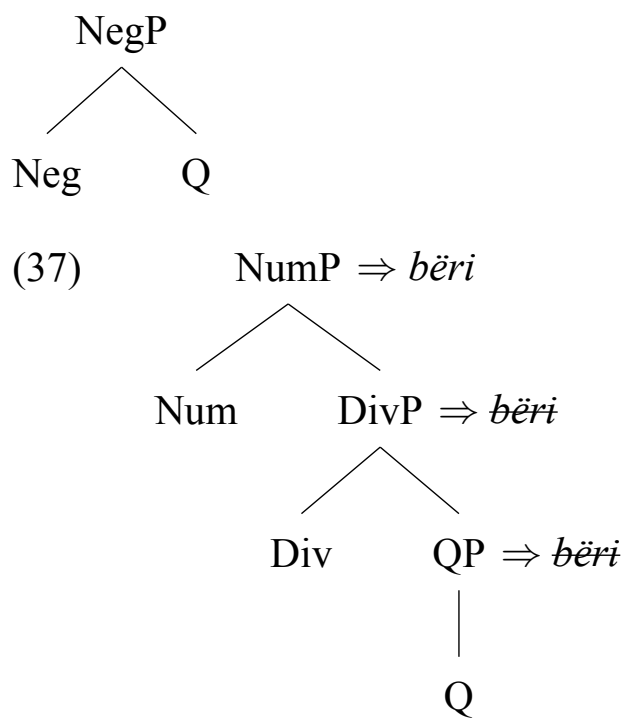

However, at the level of NegP there is no matching lexical item to be found that has the syntactic tree in (38) as a subtree.

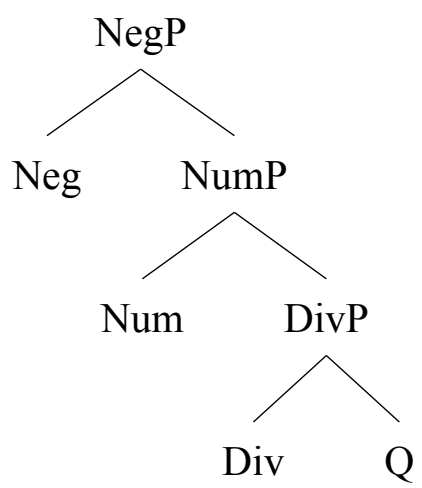

In order to spellout NegP, NumP moves to SpecNegP, yielding the structure in (39). 


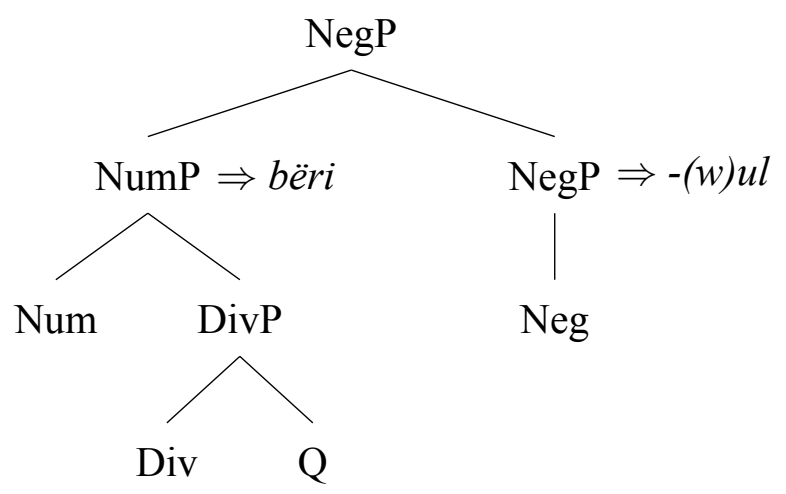

Adopting De Clercq $(2013 ; 2017)$ account for the internal structure of negative markers, Wolof's lexical item for sentential negation can be represented as in (40).

$$
</ \mathrm{u}(1) /, \text { [TP T [FocP Foc [DivP Div [QP } \mathrm{Q}[\mathrm{NegP} \text { Neg }]]]]>
$$

Given that this lexical item has a Neg as its anchor, (40) can be inserted in (39) at NegP due to the Superset Principle. If a language does not have a lexical item for NQ-words, it will take recourse to a negative marker. Based on my sample, it seems that this marker is the marker for sentential negation. An interesting observation in this respect is the fact that all languages in the sample (apart from Japanese, which also has a more complex NQ-word construction) with analytic NQ-words have a syncretic negative marker for all different scopal positions. I intend to take this up in future research.

\section{Conclusion}

This paper presented data from a diversified language sample. I argued that there is typological evidence to decompose Q-words into at least four features arranged hierarchically in a functional sequence: $<\mathrm{Neg}$, Num, Div, Q $>$. By means of these features and the nanosyntactic framework, syncretisms between count and mass Q-words and between opaque and analytic NQ-words can accounted for. Differences between languages are the result of the size and organisation of lexically stored trees. Languages with syncretisms have less lexical entries than languages without. If a language does not have a specific lexical item dedicated for the expression of NQ-words, then the meaning of the NQ-word is expressed by means of the positive Q-word and the sentential negative marker. This option is available thanks to the Superset Principle, which allows insertion of the sentential negative marker when syntax merges Neg. 


\section{References}

Baker, Mark \& Jim McCloskey. 2007. "On the relationship of typology to theoretical syntax." Linguistic Typology 11: 285-296.

Barbiers, Sjef. 2007. "Indefinite numerals ONE and MANY and the cause of ordinal suppletion." Lingua 117: 859-880.

Baunaz, Lena, Karen De Clercq, Liliane Haegeman \& Eric Lander, eds. to appear. Exploring Nanosyntax. Oxford: Oxford University Press.

Beghelli, Filippo. 1995. "The phrase structure of quantifier scope.” PhD diss., UCLA.

Bobaljik, Jonathan. 2012. Universals In Comparative Morphology. Cambridge, MA: MIT Press.

Borer, Hagit. 2005. The Normal Course of Events. Oxford: Oxford University Press.

Brasoveanu, Adrian, Karen De Clercq, Donka Farkas \& Floris Roelofsen. 2014. "Question tags and sentential negativity." Lingua 145: 173-193.

Bresnan, Joan. 1973. "Syntax of the comparative clause construction in English." Linguistic Inquiry 4: 275-343.

Broekhuis, Hans \& Marcel den Dikken. 2012. The Syntax of Dutch. Nouns and Noun Phrases, vol. 2. Amsterdam: Amsterdam University Press.

Caha, Pavel. 2009. “The nanosyntax of case.” PhD diss., University of Tromsø, Tromsø.

Caha, Pavel \& Marina Pantcheva. 2012. "Contiguity beyond linearity." Talk at Decennium: The first 10 years of CASTL.

Collins, Chris \& Paul Postal. 2014. Classical NEG raising. Cambridge, MA: MIT Press.

Corver, Norbert. 1997. "Much-support as a last resort.” Linguistic Inquiry 28: 119-164.

Corver, Norbert \& Henk van Riemsdijk, eds. 2013. Semi-lexical Categories. The Function of Content Words and the Content of Function Words. Berlin: Mouton de Gruyter.

Cowper, Elizabeth \& Daniel Currie Hall. 2012. "Aspects of individuation.” Count and Mass across Languages, ed. by Diane Massam, 27-53. Oxford: Oxford University Press.

De Clercq, Karen. 2013. “A unified syntax of negation.” PhD diss., Ghent University, Gent.

De Clercq, Karen. 2017. “The nanosyntax of French negation.” Studies on Negation: Syntax, Semantics, and Variation, ed. by Silvio Cruschina, Katharina Hartmann \& Eva-Maria Remberger, 49-80. Vienna: Vienna University Press. 
De Clercq, Karen \& Guido Vanden Wyngaerd. 2017. "Why affixal negation is syntactic." Proceedings of WCCFL 34, ed. by Aaron Kaplan, Abby Kaplan, Miranda McCarvel \& Edward Rubin, 151-158. Sommerville, MA: Cascadilla Press.

Heim, Irene. 2006. "Little." Proceedings of SALT XVI, ed. by Masayuki Gibson \& Jonathan Howell, 35-58. Cornell University.

Huddleston, Rodney \& Geoffrey K. Pullum. 2002. The Cambridge Grammar of the English Language. Cambridge: Cambridge University Press.

Keenan, Edward L. \& Denis Paperno, eds. 2012. Handbook of Quantifiers in Natural Language. Dordrecht: Springer.

Khanjian, Hrayr. 2012. "Quantification in Western Armenian." Handbook of Quantifiers in Natural Language, ed. by Edward Keenan \& Denis Paperno, 845-890. Dordrecht: Springer. Klima, Edward. 1964. "Negation in English.” The Structure of Language, ed. by Jerry Fodor \& Jerrold Katz, 246-323. Englewood Cliffs, NJ: Prentice-Hall.

Neeleman, Ad, Hans van de Koot \& Jenny Doetjes. 2006. "Degree expressions." The Linguistic Review 21: 1-66.

Partee, Barbara. 1989. "Many quantifiers." Proceedings of ESCOL, ed. by Joyce Powers \& Kenneth de Jong, vol. 5, 383-402. Columbus, OH: Department of Linguistics, Ohio State University.

Quirk, Randolph, Sidney Greenbaum, Geoffrey Leech \& Jan Svartvik. 1985. A Comprehensive Grammar of the English Language. London: Longman.

Rett, Jessica. 2016. "The semantics of many, much, few and little.” Ms. UCLA.

Rijkhoff, Jan, Dik Bakker, Kees Hengeveld \& Peter Kahrel. 1993. “A method of language sampling." Studies in Language 17: 169-203.

Ritter, Elizabeth. 1992. “Cross-linguistic evidence for number phrase." Canadian Journal of Linguistics 37: 197-218.

Ruys, Eddy G. 2017. “Two Dutch many's and the structure of pseudo-partitives.” Glossa 2(1): $1-33$.

Solt, Stephanie. 2015. "Q-adjectives and the semantics of quantity." Journal of Semantics 32(2): $221-273$.

Starke, Michal. 2009. "Nanosyntax: A short primer to a new approach to language." Nordlyd 36: $1-6$. 
Starke, Michal. 2014. "Towards elegant parameters: Language variation reduces to the size of lexically-stored trees." Linguistic Variation in the Minimalist Framework, ed. by M. Carme Picallo, 140-152. Oxford: Oxford University Press.

Tamba, Khady, Harold Torrence \& Malte Zimmerman. 2012. "Wolof quantifiers." Handbook of Quantifiers in Natural Language, ed. by Edward Keenan \& Denis Paperno, 891-940. Dordrecht: Springer.

Torrence, Harold. 2013. The clause structure of Wolof. Amsterdam: John Benjamins. 